DOI: $10.46340 /$ eppd.2020.7.2.16

Юрій Лавренюк, к. ю. н.

Національний університет "Одеська юридична академія», Україна

КАТЕГОРІЯ «АДМІНІСТРАТИВНО-ПРАВОВЕ

ЗАБЕЗПЕЧЕННЯ»: ФІЛОСОФСЬКІ ТА

МЕТОДОЛОГІЧНІ ПІДХОДИ У КОНТЕКСТІ

ЗАБЕЗПЕЧЕННЯ ЕКОНОМІЧНИХ ІНТЕРЕСІВ

УКРАЇНИ

Yurii Lavreniuk, PhD in Law

ORCID ID: https://orcid.org/0000-0002-1382-0388

National University "Odesa Law Academy», Ukraine

\title{
ADMINISTRATIVE LEGAL SUPPLY CATEGORY: PHILOSOPHICAL AND METHODOLOGICAL APPROACHES IN THE CONTEXT OF PROVIDING ECONOMIC INTERESTS OF UKRAINE
}

The article is devoted to defining the peculiarities of the content of the category of "administrative and legal supply" in the context of securing the economic interests of Ukraine, forming on this basis its modern concept in the specified context, defining the directions of its further development. It is substantiated that further study of the concept of "administrative and legal supply of the economic interests of Ukraine" should be based on the application of the modern paradigm of legal knowledge, which includes, among other things, the principles of intersubjectivity, interdisciplinarity and methodological pluralism. At the conceptual level, the concept should be based on the use of the optimal combination of axiological, anthropological, and hermeneutic concepts. At the instrumental level, the key is to combine a functional and systematic approach that takes into account, on the one hand, the activities of the subjects of the security provided in terms of its social content and purpose, and on the other, allows determine the place of the security in the overall system of social phenomena.

Keywords: administrative and legal supply, methodological approach, economic interest, state interest, concept, administrative and legal means.

Актуальність теми. Значна кількість наукових робіт у сфері адміністративного права має у назві термін «адміністративно-правове забезпечення». Разом із тим, ознайомлення із їх змістом дає підстави казати про відсутність єдиного підходу у доктрині адміністративного права щодо змісту цієї категорії. Розбіжності стосуються окремих ії ознак, а також питань співвідношення з іншими категоріями доктрини адміністративного права, що мають методологічне спрямування, наприклад адміністративно-правове регулювання.

Зокрема, описуючи вказану категорію стосовно до діяльності різних суспільних інститутів (національна безпека тощо), автори єдині у своїй позиції щодо мети такого забезпечення підтримання сталого функціонування та розвитку конкретного суспільного інституту, забезпечення його відповідності суспільним потребам. Натомість, окремі дослідники адміністративно-правового забезпечення у сфері національної безпеки вказують на несформованість такої системи, що виражається у недостатньому рівні розвитку окремих ключових ії підсистем (діяльність недержавних суб'єктів у цьому напрямі) ${ }^{1}$.

1 Ліпкан, В.А. (2008). Адміністративно-правові основи забезпечення національної безпеки України: дис. ... Д-ра юрид. наук. Київ, 106, 120. 
Водночас, інтенсивна трансформація ринкових відносин, активна взаємодія України з іншими суб'єктами міжнародних економічних відносин вимагає вироблення оновленої теоретичної основи адміністративно-правового забезпечення економічних інтересів України.

Огляд останніх досліджень і публікацій. Питанням адміністративно-правового регулювання економіки приділяли увагу такі дослідники, як В.В. Галунько, М.В. Жернаков, А.О. Монаєнко, Т.О. Проценко та інші. Втім, комплексного висвітлення проблематика цієї статті не отримала.

Метою статті $\epsilon$ визначення особливостей змісту категорії «адміністративно-правове забезпечення» у контексті забезпечення економічних інтересів України, формування на цій основі їі сучасного концепту у вказаному контексті, визначення напрямів його подальшого розвитку.

Основний матеріал. Представники економічної наукової спільноти відмічають ключовий характер публічного регулювання сучасної економіки для її ефективного розвитку. 3 іншого боку, належно розвинута економіка $є$ однією з запорук належної реалізації та розвитку правової системи ${ }^{1}$. 3 подібних позицій виходять й наукові дослідження, що розглядають проблематику співвідношення методів державного регулювання планової та ринкової економіки ${ }^{2}$. Актуальність міждисциплінарного підходу при опрацюванні сутності адміністративно-правового забезпечення економічних інтересів України слідує з наукових робіт не тільки вчених-економістів, але й вченихюристів, що займаються проблематикою у точці дотику права та економіки. Зокрема, О.Ф. Скакун вказує на неминучість досліджень міждисциплінарного характеру, необхідність залучення юристів та економістів для спільних наукових досліджень не тільки у дотичних питаннях з цих сфер, але й в усіх інших питаннях права та економіки ${ }^{3}$.

Ключові напрями забезпечення економічних інтересів у сучасному суспільстві можуть бути визначені виходячи з положень, які наводяться усфері економічної теорії. Зокрема, по-перше суб'єктами публічної влади здійснюється перерозподіл засобів, що складають внутрішній валовий продукт. По-друге, діяльність вказаних суб'єктів передбачає генезу системи управління ${ }^{4}$, ефективність якої й складає важливий фактор забезпечення економічних інтересів.

У найбільш загальному розумінні адміністративно-правове забезпечення пов'язується із комплексом певних заходів, що вживаються суб' єктами державної влади для досягнення визначеної суспільної мети 5 .

За результатами дослідження сутності адміністративно-правового забезпечення протидії корупції, В.І. Литвиненко визначає його сутність як механізм врегулювання суспільних відносин. При цьому вчений центральне значення віддає правовому статусу суб'єктів державної влади, що безпосередньо здійснюють боротьбу із корупцією. Зокрема, досліджуються мета й завдання таких суб'єктів, принципи, методи та форми їх діяльності ${ }^{6}$. Коментуючи таку позицію, необхідно вказати на її відносно вузький характер, оскільки вченим враховано, переважно, структура правового статусу суб'єктів забезпечення протидії корупції. Втім, поза увагою залишаються інші суспільні інститути, що вносять вагомий вклад у виконання цього завдання: діяльність громадських організацій, приватних осіб, загальні та спеціально юридичні гарантії забезпечення режиму верховенства права та інші. Крім того, вразливим місцем цієї позиції можна визначити вжиття не усталеного терміну «механізм», що у теорії права отримав поширеність стосовно адміністративно-правового регулювання, а не адміністративно-правового забезпечення.

\footnotetext{
${ }^{1}$ Броцкий, М.Н. (2002). Государственно-правовое регулирование экономической деятельности в современной России (теоретическая модель и практическое воплощение): дисс. ... д-ра. юрид. наук. Санкт-Петербург, 9.

2 Босак, О.3. (2010). Публічне управління як нова модель управління у державному секторі. Державне управління: теорія і практика, 2, 114-122.

${ }^{3}$ Петришин, О.В., Битяк, Ю.П. (заг. ред. та ін.) (2013). Правова доктрина України: в 5 т. Харків: Право, T.1: Загальнотеоретична та історична юриспруденщія, 155; Баренбойм, П.Д. (2009). Философия права и конституционная экономика. Очерки Конституционной экономики. Москва: Юстиц-информ, 262; Тильчик, О.В. (2018). Адміністративно-правове забезпечення протидї тінізаиії економіки: теорія $i$ практика: дис. ... д-ра. юрид. наук: 12.00.07. Ірпінь, 185.

${ }^{4}$ Норт, Д. (1997). Институты, институцииональные изменения и функциионирование экономики. Москва: Фонд экономической книги «Начала», 10.

${ }^{5}$ Римарчук, Г.С. (2013). Адміністративно-правове забезпечення права інтелектуальної власності в Украӥні: автореф. дис. ... канд. юрид. наук. Львів, 14-15.

${ }^{6}$ Литвиненко, В.І. (2015). Концеепція адміністративно-правового забезпечення протидї̈ корупиії в Україні: дис. ... д-ра. юрид. наук. Київ, 49-50.
} 
Окремі вчені характеризують адміністративно-правове забезпечення з позиції механізму адміністративно-правового регулювання. Так, дослідники адміністративно-правового забезпечення прав і свобод неповнолітніх окремо виділяють поняття «адміністративно-правове забезпечення» та «механізм адміністративно-правового забезпечення». При цьому система норм адміністративного права та суб’єкти такого забезпечення мають бути віднесені саме до елементів механізмуㄹ.

Охарактеризоване різноманіття наукових підходів щодо визначення категорії «адміністративно-правове забезпечення» може бути пояснене, у першу чергу, принципово різними сферами суспільного життя, щодо якого вона розглядається у конкретному випадку. Це зумовлює й необхідність застосування різних засобів досягнення відповідних завдань. Крім того, міждисциплінарний характер відповідних термінів (корупція, національна безпека) зумовлює й особливості методології наукових досліджень у конкретних випадках, а отже - отриманих висновків. Подібних висновків доходять й окремі вчені у сфері теорії права, які при цьому виділяють такі елементи адміністративно-правового забезпечення: суб'єкт; об'єкт; норми права; адміністративноправові відносини; методи й форми, засоби, заходи, гарантій такого забезпечення ${ }^{2}$.

О.В. Тильчик, досліджуючи сутність адміністративно-правового забезпечення протидії тінізації економіки, виходить з необхідності врахування характеру діяльності суб'єктів такого забезпечення, а також їх адміністративно-правового статусу. Такого висновку вчена доходить з урахуванням змісту предмету сучасного адміністративного права. Крім того, на інструментальному рівні методології правового пізнання пропонується застосування системного підходу, що передбачає дослідження розглядуваного напряму адміністративно-правового забезпечення як підсистеми правового забезпечення економічної безпеки загалом ${ }^{3}$ Безумовною перевагою такого підходу є його методологічна обгрунтованість, оскільки виключається отримання результатів, що за своєю сутністю виходять за межі адміністративного права. Крім того, застосування системного підходу дозволяє врахувати призначення не тільки власне досліджуваної системи, але й - у контексті системи вищого порядку.

Виходячи з наведених досліджень, можна констатувати, що сьогодні недостатньою мірою $є$ сформованим не тільки склад ознак досліджуваної категорії, але й сам методологічний підхід до неї. Такий підхід значною мірою залежить від співвідношення таких понять, як «адміністративно-правове забезпечення» та «адміністративно-правове регулювання», оскільки друге поняття, на нашу думку, відображає галузевий (правовий аспект) адміністративно-правового забезпечення. Тому встановлення співвідношення цих понять сприятиме визначенню міждисциплінарного об'єкту адміністративно-правового забезпечення економічних інтересів України. В аспекті подальшого дослідження, для розмежування вказаних понять, вважаємо за доцільне врахувати позицію В.П. Нагребельного щодо необхідності розмежування понять «адміністративно-правовий вплив» та «адміністративно-правове регулювання». Адміністративно-правове регулювання розглядається як один із засобів адміністративно-правового впливу, що передбачає вплив і не правовими засобами ${ }^{4}$ Хоча предметом цього дослідження охоплюється та частина адміністративно-правового забезпечення економічних інтересів, що здійснюється виключно правовими засобами, але позиція відомого вченого звертає увагу на мету такого забезпечення - ним є саме вплив. Тому мета такого забезпечення за своїм змістом виходить за суто правові межі.

Іншою категорією, що має бути з'ясована, $\epsilon$ категорія економічного інтересу держави. У національній правовій системі держава постає одним з учасників правовідносин 5 . 3 цього ж виходять дослідники широкого спектру правових галузей сучасної національної правової системи -

\footnotetext{
${ }^{1}$ Корж-Ікаєва, Т.Г. (2008). Адміністративно-правове забезпечення прав і свобод неповнолітніх: автореф. дис. ... канд. юрид. наук. Київ, С. 7-8.

${ }^{2}$ Гумін, О.М., Пряхін, С.В. (2014). Адміністративно-правове забезпечення: поняття та структура. Наше право, $4,49$.

3 Тильчик, О.В. (2018). Адміністративно-правове забезпечення протидї̈ тінізації економіки: теорія $i$ практика: дис. ... д-ра юрид. наук: 12.00.07. Ірпінь, 183.

${ }^{4}$ Нагребельний, В.П. (2015). Сучасна доктрина адміністративно-правового регулювання в контексті забезпечення прав громадян органами публічної адміністрації. Адміністративно-правове забезпечення прав людини органами публічної адміністрації в Україні: збірник наукових праць. Київ: Інститут держави і права ім. В.М. Корецького НАН України, 10.

${ }^{5}$ Петришин, О.В. (ред.) (2015). Теорія держави і права: підручник. Харків: Право, 234.
} 
від теорії права до цивільного процесуального права ${ }^{1}$. Отже, категорія «інтерес» може бути застосована до неї у розумінні, подібному до тому, що застосовується до інтересів особи - фізичної чи юридичної ${ }^{2}$. Специфіка ознаки «державності» інтересу може бути визначена виходячи 3 позиції, що є усталеною, міститься у рішенні Конституційного Суду України від 01.12.2004 p. № 18-рп/2004. Зокрема, можливо виокремити наступні специфічні ознаки державного інтересу: спрямованість (реалізація загальнодержавних програм, потреб), формальна вираженість (закріплення у відповідних загальнодержавних програмах, планах, стратегіях тощо) ${ }^{3}$. Саме за вказаними ознаками інтерес держави, будучи суб'єктивним за своєю природою, не може бути охарактеризований як приватний. 3 позицій, що наводяться у юридичній літературі, можна дійти висновку щодо сутності економічного інтересу держави: а) зумовленість об'єктивними економічними потребами держави; б) прагнення до задоволення цих потреб ${ }^{4}$. Отже, можна виділити наступні ознаки економічного інтересу держави: будучи об'єктивно вираженим, тим не менш носить суб'єктивний характер; його сутністю є прагнення держави до задоволення власних економічних потреб.

Невдача у реалізації концепції планової економіки вбачається окремими дослідниками саме у прорахунках при застосуванні командно-адміністративних методів іiї врегулювання 5 . Згодом, при переході економіки на ринкові рейки відповідним чином постало питання й про зміну адміністративних методів врегулювання відповідних процесів, зокрема поширення застосування заохочувальних засобів або методу координації.

Актуальною засадою адміністративно-правового регулювання економіки можна вважати твердження щодо неприпустимості втручання суб'єктів публічної влади у економічні процеси під загрозою втрати ефективності економікою. Основною гарантією належного функціонування економіки визначається іiі саморегулівний характер ${ }^{6}$. Необхідно вказати про саме загальний характер такого твердження, оскільки повна дерегуляція економіки може призвести до появи недобросовісної конкуренції, втрати такою економікою соціальної орієнтованості. Крім того, необхідно погодитись із висловлюваними у сфері економічної теорії позиціями щодо недостатності засобів саморегуляції економіки до подолання глибоких економічних криз ${ }^{7}$.

Ще однією важливою функцією державного регулювання економічних процесів наводиться забезпечення довгострокових грошових накопичень ${ }^{8}$. Не буде помилкою вказати про забезпечення досягнення довгострокових завдань загалом, або таких результатів, які не мають характеру окупності, але $\epsilon$ необхідними для задоволення потреб суспільства.

Сьогодні вирізняють наступні актуальні завдання державного регулювання економіки засобами адміністративного права: створення умов для реалізації визначальних напрямів розвитку економіки

\footnotetext{
${ }^{1}$ Рябченко, Ю.Ю. (2018). Проблематика определения категорий «субъект права», «участник судебного процесса» в национальной правовой доктрине. Legea si viata, 10/2, 94.

2 Рішення Конституційного Суду Украӥни у справі за конституційними поданнями Вищуого арбітражсного суду Украӥни та Генеральної прокуратури Украӥни щзодо офіційного тлумачення положень статті 2 Арбітражного процесуального кодексу Украӥни (справа про представництво прокуратурою України інтересів держави в арбітражному суді) 1999 (Конституційний Суд України). Офіційний вісник України, 15, 35, 614.

${ }^{3}$ Рішення У справі за конституційним поданням 50 народних депутатів України щзодо офіційного тлумачення окремих положень частини першої статті 4 Цивільного прочесуального кодексу України (справа про охоронюваний законом інтерес) 2004 (Конституційний Суд України). Офіційний вісник Украӥни, 50, $67,3288$. ${ }^{4}$ Мельник, С., Горбан, І., Цуп, М. (2014). Сутність і класифікація національних економічних інтересів. Науковий вісник Львівського державного університету внутрішніх справ, 1, 64.

${ }_{5}^{5}$ Орлов, В.И. (2001). Стимулирование как метод повышения эффективности государственного управления в сфере экономики. Административное право: теория и практика. Укрепление государства и динамика социально-экономического развития: материалы научной конференции (Москва, 28 ноября 2001 г.). Москва, 264; Тильчик, О.В. (2018). Адміністративно-правове забезпечення протидії тінізації економіки: теорія $i$ практика: дис. ... д-ра. юрид. наук: 12.00.07. Ірпінь, 186.

${ }^{6}$ Фрідман, М. (2017). Капіталізм і свобода. Київ: Наш формат.

${ }^{7}$ Норт, Д. (1997). Институты, институциональные изменения и функционирование экономики. Москва: Фонд экономической книги «Начала», 10.

${ }^{8}$ Турбанов, А.В. (2004). Финансово-правовые основы создания и функциионирования системы страхования банковских вкладов в Российской Федерации: дисс. ... д-ра. юрид. наук. Москва, 11-12; Тильчик, О.В. (2018). Адміністративно-правове забезпечення протидії тінізації економіки: теорія і практика: дис. ... д-ра. юрид. наук: 12.00.07. Ірпінь, 188.
} 
(стимулювання окремих сфер економічних відносин, інвестування тощо; відслідковування можливих сфер поширення недержавної власності, способів іiї набуття (наприклад, врегулювання конкуренції); управління зовнішньоекономічною діяльністю; забезпечення відповідності методів та засобів адміністративно-правового регулювання економічних відносин суспільному запиту щодо них (оптимальне застосування таких засобів. як ліцензування, патентування, квотування, дозвільної діяльності тощо) ${ }^{1}$. При цьому ключовою можна вважати позицію Н.Р. Нижник щодо суті сучасного публічного управління економікою: створення умов для саморозвитку сприятливих факторів та для самоблокування негативних ${ }^{2}$.

Характеризуючи економічні інтереси держави як об'єкт адміністративно-правового регулювання, необхідно відмітити логічний характер наукових позицій окремих вчених щодо застосування вказаних засобів регулювання економіки. Зокрема, О.П. Рябченко, відмічаючи актуальність проблематики оптимального застосування засобів публічного регулювання господарської діяльності, бачить істотну проблему її вирішення: мінливість господарської діяльності, iї пріоритетів ${ }^{3}$. Дійсно, вказана обставина заважає побудові чітких та сталих критеріїв застосування засобів вказаного регулювання.

Застосування міждисциплінарного підходу до дослідження сутності адміністративноправового забезпечення економічних інтересів України дозволяє сформулювати його з позиції адміністративного права. Базовою характеристикою спрямованості такого забезпечення постають визначальні завдання адміністративного права: уточнення змісту та обсягу приватних прав, свобод, законних інтересів, реалізація яких забезпечується суб' єктами здійснення адміністративно-правового регулювання; вдосконалення адміністративно-правових засобів та способів реалізації зазначених прав та обов'язків; забезпечення ефективної роботи актуальних суспільних інститутів; вдосконалення адміністративного процесуального регулювання діяльності суб'єктів публічної влади; розвиток гарантій здійснення публічного контролю за діяльністю суб'єктів публічної влади; розвиток інституту адміністративно-правової відповідальності ${ }^{4}$.

Окремо необхідно виділити правозахисну функцію адміністративного права, оскільки вона реалізується в особливому правовому полі. Адже усі наведені вище завдання передбачають правомірний характер поведінки учасників економічних відносин. Такі заходи спрямовані на запобігання поведінці, обмежує приватні права, свободи, законні інтереси інших осіб 5 .

Напрями адміністративно-правового забезпечення економічних інтересів України зумовлюються, з іншого боку, визначальними векторами розвитку економіки, що отримали закріплення в економічній теорії: обсяг та перелік товарів, які необхідно виробляти; способи їх вироблення; кінцеві споживачі таких товарів ${ }^{6}$.

В окремих роботах у сфері державного управління висловлюються позиції щодо необхідності врахування надбань у сфері соціології, оскільки методи та засоби державного управління мають враховувати менталітет населення конкретної території чи конкретної держави, в тому числі погляди щодо оптимального поєднання матеріального і духовного в державі та суспільстві загалом та людині зокрема ${ }^{7}$. Виходячи 3 положень щодо актуальних завдань соціології ${ }^{8}$, можна визначити наступні ключові до врахування соціологічні фактори належного адміністративно-правового забезпечення економічних інтересів України: поширений стиль мислення та ідеологія людей, особливо тих, що

\footnotetext{
${ }^{1}$ Галунько, В., Діхтієвський, П., Кузьменко, О., Стеценко, С. (2018). Адміністративне право Украӥни. Повний курс: підручник. Херсон: ОЛДІ-ПЛЮС, 340-343.

2 Петришин, О.В., Битяк, Ю.П. (заг. ред.) (2013). Правова доктрина України: в 5 т. Харків: Право, T. 2:

Публічно-правова доктрина України, 114.

${ }^{3}$ Рябченко, О.П. (2013). Конщептуальні проблеми застосування диспозитивного методу публічно-правового регулювання відносин у сфері економіки: наукова доповідь. Київ: Логос, 19-21.

${ }^{4}$ Галунько, В., Діхтієвський, П., Кузьменко, О., Стеценко, С. (2018). Адміністративне право Украӥни. Повний курс: підручник. Херсон: ОЛДІ-ПЛЮС, 26-28.

${ }_{5}^{5}$ Мазаев, Д.В. (2013). Соотношение категорий «правовая охрана» и «правовая защита» в контексте отраслей российского права и законодательства. Общество и право, 4 (46), 28.

${ }^{6}$ Комарницький, І.Ф. (2006). Економічна теорія: навчальний посібник. Чернівці, 58.

${ }^{7}$ Позняков, С.П. (2014). Адміністративно-правове сприяння соціально-економічному розвитку в Украӥні: теоретико-методологічні засади: монографія. Київ: НУБіП України, 245-246; Тильчик, О.В. (2018). Адміністративно-правове забезпечення протидї тінізації економіки: теорія і практика: дис. ... д-ра. юрид. наук: 12.00.07. Ірпінь, 195.

${ }^{8}$ Дворецька, Г.В. (2001). Соціологія: навчальний посібник. Київ: КНЕУ, 33.
} 
займають посади у складі суб'єктів публічної влади та здійснюють державне регулювання у сфері економіки, в тому числі- соціальна активність; актуальне співвідношення загальнолюдських, колективних, індивідуальних стосунків та інтересів в Україні. Таким чином, концепт адміністративно-правового забезпечення економічних інтересів України має міждисциплінарний зміст, оскільки має враховувати дані суміжних (у даному випадку) дисциплін, зокрема економіки та соціології. Зокрема, перші дають змогу враховувати закономірності розвитку економіки загалом або iї конкретної сфери. Другі дають змогу враховувати закономірності розвитку як суспільних, так i колективних, індивідуальних інтересів, що $\epsilon$ неодмінною передумовою ефективності адміністративно-правового регулювання. Вказаний міждисциплінарний характер складає особливість категорії адміністративно-правового забезпечення економічних інтересів України. Крім того, підлягають врахуванню наукові надбання загального характеру, філософії, філософії права, теорії права, кримінології та деяких інших.

Проведене дослідження надає підстави для таких висновків:

Таким чином, опрацювання та подальше дослідження концепту «адміністративно-правове забезпечення економічних інтересів України» має базуватись на застосуванні сучасної парадигми правового пізнання, що передбачає, в тому числі, засади інтерсубєктивності, міждисциплінарності та методологічного плюралізму. На концептуальному рівні зазначений концепт має вибудовуватись на основі застосування оптимального поєднання аксіологічної, антропологічної та герменевтичної концепцій. На інструментальному рівні ключовим $є$ поєднання функціонального та системного підходу, що дозволяє врахувати з одного боку, діяльність суб'єктів зазначеного забезпечення 3 позиції iï соціального змісту та призначення, а з іншого - дозволяє визначити місце вказаного забезпечення у загальній системі соціальних явищ.

Адміністративно-правове забезпечення економічних інтересів України як концепт у доктрині адміністративного права може бути визначений у вузькому та широкому розумінні. У вузькому розумінні ним є відповідні адміністративно-правові засоби та способи, спрямовані на забезпечення задоволення вказаних інтересів держави Україна. У широкому розумінні такими засобами $є$ й інші суспільні інститути, що виходять за межі змісту адміністративного права, але використовуються разом із ними та сприяють досягненню зазначеної мети (наприклад, забезпечення належного фінансування діяльності суб'єктів забезпечення економічних інтересів держави Україна).

Зазначений концепт передбачає відповідність засобів адміністративно-правового регулювання потребам поточного стану економіки та соціальної реальності. Диспозитивний характер вказаного забезпечення передбачає створення умов задоволення державою своїх економічних потреб. Імперативний його характер передбачає жорсткий контроль та владний вплив на діяльність суб'єктів господарювання та інших суб'єктів, що забезпечують економічні інтереси України.

3 методологічної (інструментальної) точки зору оптимальним є поєднання системного та функціонального підходів, враховуючи міждисциплінарний характер досліджень. Функціональний підхід відображає систему суб'єктів адміністративно-правового забезпечення та їх діяльність (функціонування). Системний підхід відображає міждисциплінарний характер зазначених категорій та їх співвідношення, дозволяє охарактеризувати призначення вказаного забезпечення не тільки в контексті власне економічних інтересів, але й в більш широкому вимірі - національної безпеки.

\section{References:}

1. Barenbojm, P.D. (2009). Filosofija prava i konstitucionnaja jekonomika. Ocherki Konstitucionnoj jekonomiki [Philosophy of law and constitutional economics. Essays on Constitutional Economics]. Mosvow: Justic-inform. [in Russian].

2. Bosak, O.Z. (2010). Publichne upravlinnia yak nova model upravlinnia u derzhavnomu sektori [Public administration as a new model of government in the public sector]. Derzhavne upravlinnia: teoriia i praktyka [Public administration: theory and practice], no. 2, 114-122. [in Ukrainian].

3. Brockij, M.N. (2002). Gosudarstvenno-pravovoe regulirovanie jekonomicheskoj dejatel 'nosti v sovremennoj Rossii (teoreticheskaja model' i prakticheskoe voploshhenie): diss. ... d-ra. jurid. nauk [State-legal regulation of economic activity in modern Russia (theoretical model and practical implementation): Diss. ... dr. legal of sciences]. Saint Petersburg. [in Russian].

4. Halunko, V., Dikhtiievskyi, P., Kuzmenko, O., Stetsenko, S. (2018). Administratyvne pravo Ukrainy. Povnyi kurs: pidruchnyk [Administrative law of Ukraine. Full course: textbook]. Kherson: OLDI-PLIuS. [in Ukrainian].

5. Humin, O.M., Priakhin, Ye.V. (2014). Administratyvno-pravove zabezpechennia: poniattia ta struktura [Administrative and legal support: concept and structure]. Nashe pravo [Our law], no. 4, 49. [in Ukrainian].

6. Dvoretska, H.V. (2001). Sotsiolohiia: navchalnyi posibnyk [Sociology: a textbook]. Kyiv: KNEU. [in Ukrainian]. 
7. Komarnytskyi, I.F. (2006). Ekonomichna teoriia: navchalnyi posibnyk [Economic theory: a textbook]. Chernivtsi. [in Ukrainian].

8. Korzh-Ikaieva, T.H. (2008). Administratyvno-pravove zabezpechennia prav i svobod nepovnolitnikh: avtoref. dys. ... kand. yuryd. nauk [Administrative and legal support of the rights and freedoms of minors: abstract. Thesis of $\mathrm{PhD}$ of Law]. Kyiv. [in Ukrainian].

9. Lytvynenko, V.I. (2015). Kontseptsiia administratyvno-pravovoho zabezpechennia protydii koruptsii v Ukraini: dys. ... d-ra. yuryd. nauk [The concept of administrative and legal support of combating corruption in Ukraine: thesis Dr.of Law]. Kyiv. [in Ukrainian].

10. Lipkan, V.A. (2008). Administratyvno-pravovi osnovy zabezpechennia natsionalnoi bezpeky Ukrainy: dys. ... d-ra yuryd. nauk [Administrative and Legal Foundations of National Security of Ukraine: thesis Dr.of Law]. Kyiv. [in Ukrainian].

11. Mazaev, D.V. (2013). Sootnoshenie kategorij «pravovaja ohrana» i «pravovaja zashhita»v kontekste otraslej rossijskogo prava i zakonodatel'stva [Correlation of the categories of "legal protection" and "legal protection" in the context of branches of Russian law and legislation]. Obshhestvo i pravo [Society and Law], no. 4 (46), 28. [in Russian].

12. Melnyk, S., Horban, I., Tsup, M. (2014). Sutnist i klasyfikatsiia natsionalnykh ekonomichnykh interesiv [The essence and classification of national economic interests]. Naukovyi visnyk Lvivskoho derzhavnoho universytetu vnutrishnikh sprav [Bulletin of the Lviv State University of Internal Affairs], no. 1, 64. [in Ukrainian].

13. Nahrebelnyi, V.P. (2015). Suchasna doktryna administratyvno-pravovoho rehuliuvannia v konteksti zabezpechennia prav hromadian orhanamy publichnoi administratsii [Modern doctrine of administrative and legal regulation in the context of ensuring the rights of citizens by public administration bodies]. Administratyvnopravove zabezpechennia prav liudyny orhanamy publichnoi administratsii $v$ Ukraini: zbirnyk naukovykh prats [Administrative Legal Support of Human Rights by Public Administration Bodies in Ukraine: Collection of Scientific Papers]. Kyiv: Instytut derzhavy i prava im. V.M. Koretskoho NAN Ukrainy, 10. [in Ukrainian].

14. Nort, D. (1997). Instituty, institucional 'nye izmenenija i funkcionirovanie jekonomiki [Institutions, institutional changes and the functioning of the economy]. Moscow: Fond jekonomicheskoj knigi «Nachala». [in Russian].

15. Orlov, V.I. (2001). Stimulirovanie kak metod povyshenija jeffektivnosti gosudarstvennogo upravlenija v sfere jekonomiki. Administrativnoe pravo: teorija i praktika [Stimulation as a method of increasing the efficiency of public administration in the economic sphere. Administrative Law: Theory and Practice]. Ukreplenie gosudarstva I dinamika social'no-jekonomicheskogo razvitija: materialy nauchnoj konferencii (Moskva, 28 nojabrja 2001 g.) [Strengthening the State and the Dynamics of Socio-Economic Development: Materials of a Scientific Conference (Moscow, November 28, 2001)]. Moscow, 264. [in Russian].

16. Petryshyn, O.V. (ed.) (2015). Teoriia derzhavy i prava: pidruchnyk [The theory of state and law: a textbook]. Kharkiv: Pravo. [in Ukrainian].

17. Petryshyn, O.V., Bytiak, Yu.P. (ed.) (2013). Pravova doktryna Ukrainy: v 5 t. [Legal Doctrine of Ukraine: 5 Vol.]. Kharkiv: Pravo, Vol. 2: Public Legal Doctrine of Ukraine. [in Ukrainian].

18. Petryshyn, O.V., Bytiak, Yu.P. (zah. red. ta in.) (2013). Pravova doktryna Ukrainy: v 5 t. [Legal Doctrine of Ukraine: 5 Vol.]. Kharkiv: Pravo, Vol.1: General and historical jurisprudence. [in Ukrainian].

19. Pozniakov, S.P. (2014). Administratyvno-pravove spryiannia sotsialno-ekonomichnomu rozvytku v Ukraini: teoretyko-metodolohichni zasady: monohrafiia [Administrative-legal assistance to socio-economic development in Ukraine: theoretical and methodological foundations: monograph]. Kyiv: NUBiP Ukrainy, 245-246. [in Ukrainian].

20. Rymarchuk, H.S. (2013). Administratyvno-pravove zabezpechennia prava intelektualnoi vlasnosti v Ukraini: avtoref. dys. ... kand. yuryd. nauk [Administrative and Legal Support for Intellectual Property Rights in Ukraine: Abstract. Thesis PhD of Law]. Lviv. [in Ukrainian].

21. Rishennia Konstytutsiinoho Sudu Ukrainy u spravi za konstytutsiinymy podanniamy Vyshchoho arbitrazhnoho sudu Ukrainy ta Heneralnoi prokuratury Ukrainy shchodo ofitsiinoho tlumachennia polozhen statti 2 Arbitrazhnoho protsesualnoho kodeksu Ukrainy (sprava pro predstavnytstvo prokuraturoiu Ukrainy interesiv derzhavy v arbitrazhnomu sudi) 1999 [Decision of the Constitutional Court of Ukraine in the case on the constitutional submissions of the Supreme Arbitration Court of Ukraine and the Prosecutor Generals Office of Ukraine on the official interpretation of the provisions of Article 2 of the Arbitration Procedure Code of Ukraine] (Konstytutsiinyi Sud Ukrainy) [The Constitutional Court of Ukraine]. Ofitsiinyi visnyk Ukrainy [Official Bulletin of Ukraine], 15, 35, 614. [in Ukrainian].

22. Rishennia U spravi za konstytutsiinym podanniam 50 narodnykh deputativ Ukrainy shchodo ofitsiinoho tlumachennia okremykh polozhen chastyny pershoi statti 4 Tsyvilnoho protsesualnoho kodeksu Ukrainy (sprava pro okhoroniuvanyi zakonom interes) 2004 [Decision In the case of the constitutional submission of the 50 Peoples Deputies of Ukraine regarding the official interpretation of certain provisions of the first part of Article 4 of the Civil Procedure Code of Ukraine (the case of law-protected interest)] (Konstytutsiinyi Sud Ukrainy) [The Constitutional Court of Ukraine]. Ofitsiinyi visnyk Ukrainy [Official Bulletin of Ukraine], 50, 67, 3288. [in Ukrainian]. 
23. Riabchenko, O.P. (2013). Kontseptualni problemy zastosuvannia dyspozytyvnoho metodu publichno-pravovoho rehuliuvannia vidnosyn u sferi ekonomiky: naukova dopovid [Conceptual problems of applying the dispositive method of public law regulation of relations in the sphere of economy: scientific report]. Kyiv: Lohos. [in Ukrainian].

24. Rjabchenko, Ju.Ju. (2018). Problematika opredelenija kategorij «subekt prava», «uchastnik sudebnogo processa» v nacional'noj pravovoj doktrine [The problems of determining the categories of "subject of law", "participant in the trial" in the national legal doctrine]. Legea si viata, no. 10/2, 94. [in Russian].

25. Tylchyk, O.V. (2018). Administratyvno-pravove zabezpechennia protydii tinizatsii ekonomiky: teoriia i praktyka: dys. ... d-ra. yuryd. nauk [Administrative and legal support of counteraction to the shadow economy: theory and practice: thesis Dr. Of Law]. Irpin. [in Ukrainian].

26. Turbanov, A.V. (2004). Finansovo-pravovye osnovy sozdanija i funkcionirovanija sistemy strahovanija bankovskih vkladov v Rossijskoj Federacii: diss. ... d-ra. jurid. nauk [Financial and legal basis for the creation and functioning of a bank deposit insurance system in the Russian Federation: thesis Dr. Of Law]. Moscow. [in Russian].

27. Fridman, M. (2017). Kapitalizm i svoboda [Capitalism and freedom]. Kyiv: Nash format. [in Ukrainian] 